\title{
Latitudinal diversity gradients in the deep sea with special reference to North Atlantic nematodes
}

\author{
P. J. D. Lambshead ${ }^{1, *}$, John Tietjen $^{2}$, Timothy Ferrero ${ }^{1}{ }$, Preben Jensen ${ }^{4}$ \\ ${ }^{1}$ The Nematode Research Group, Department of Zoology, The Natural History Museum, London SW7 5BD, \\ United Kingdom \\ ${ }^{2}$ Department of Biology, City College of New York, New York 10031, USA
}

\begin{abstract}
The discovery of global-scale latitudinal gradients of declining biodiversity from the tropics to the pole for bivalves, gastropods and isopods in the deep North Atlantic has created a high degree of interest and controversy. This is because such gradients are commonly associated with solar energytemperature gradients in terrestrial and shallow water systems and it is difficult to see how these processes might apply to a diversity gradient in the deep North Atlantic, where productivity increases northwards but diversity declines. Here, we compare biodiversity patterns from marine nematodes, the most abundant deep-sea metazoan, from the deep North Atlantic with previous results and show that rarefaction is potentially unsuitable for large-scale biogeographic pattern analysis. We obtain a different pattern from that previously obtained for mollusc and isopod data. Nematode diversity, as measured by species count, shows a positive gradient between 13 to $56^{\circ} \mathrm{N}$, which is consistent with the hypothesis that this pattern is related to the productivity gradient in the food-starved deep North Atlantic. The Norwegian Sea appears to be an area of low diversity for reasons connected to historicalgeographical processes.
\end{abstract}

KEY WORDS: Latitudinal gradients · Deep sea $\cdot$ North Atlantic $\cdot$ Nematodes

\section{INTRODUCTION}

The single most famous large-scale biodiversity pattern in ecology is the latitudinal gradient. Nearly 200 years' worth of data and comment on this issue have accumulated since Humboldt \& Bonpland (1807), and yet understanding the processes that give rise to such patterns is still one of the challenges for biodiversity research (Rosenzweig 1995). Convincing latitudinal gradients have been reported for terrestrial higher taxa (both plant and animal); the usual pattern is for species diversity to decline away from the equator (Rosenzweig 1995). Soil nematodes are possibly an exception in that the gradient appears reversed (Proctor 1990), although the diversity of rainforest nema-

-E-mail: pjdl@nhm.ac.uk

tDeceased todes has never been comprehensively assessed but may be high (Hodda et al. 1995).

Latitudinal gradients have been reported for marine pelagic taxa (Reid et al. 1978, Angel 1993, McGowan \& Walker 1993). The situation for marine coastal benthic fauna and flora is less clear. Classic latitudinal gradients are known for some fossil and recent groups, (Thorson 1952, Stehli et al. 1967, 1969, Sanders 1968, Roy et al. 1998). Other patterns discovered include a unimodal, temperate peak (Thorson 1957. Lasserre 1992) and reverse gradients (Santelices 1989). However, a number of other investigations have failed to discern a latitudinal component in diversity patterns for coastal benthic organisms (Gaines \& Lubchenco 1982, Hicks \& Coull 1983, Warwick \& Ruswahyuni 1987, Kendall \& Aschan 1993, Dauvin et al. 1994, Boucher \& Lambshead 1995, Coates 1998). Latitudinal gradient patterns can, therefore, be described as complex and difficult to interpret as the product of a single mechanism. 
A recent comprehensive review by Rohde (1992) examined a variety of potential mechanisms for latitudinal gradients, including competition, predation, mutualism, parasitism, host diversity, niche theory, environmental heterogeneity and disturbance. He found little evidence to support these mechanisms. Rohde reported that the most consistent correlation over large scales occurs between species diversity and temperature-solar radiation. There are 2 potential ways of interpreting this relationship; one involves ecological processes while the other involves evolutionary mechanisms.

The ecological explanation can be summed up by saying that latitudinal gradients in solar radiation cause concomitant gradients in productivity and hence gradients in diversity. The relationship between productivity and diversity is complex and is usually summarised by a unimodal curve with highest diversity recorded at intermediate levels of productivity (Grime 1973, Huston 1979, see Rosenzweig 1995 for a review). So this mechanism could give a variety of diversity patterns depending on the specific taxa and what part of the unimodal curve is relevant. Roy et al. (1998) analysed a database of 3916 prosobranch gastropods and reported a relationship between diversity and solar energy, which they ascribed to a productivity mechanism.

Rohde (1992) hypothesised that the link between solar energy and diversity is directly temperaturerelated and has suggested an evolutionary mechanism. He noted that 'tropical genera of benthic Foraminifera and bivalves tend to be younger' than their high latitude equivalents and that there are 'latitude-dependent differences in the rate of evolution in clams, mammals, Permian brachiopods and Cretaceous planktonic Foraminifera'. Rohde suggested that evolutionary speed was positively related to temperature and that this could drive the latitudinal diversity patterns observed today; warmer climates would have more species through a faster evolutionary rate given that habitats rarely seem to be saturated.

The modern deep sea is an unusual environment that has useful properties for examining these hypotheses. Excluding hydrothermal vents, productivity in the benthos is dependent on the flux of organic material from surface productivity and lateral transport from the continents. The second point about productivity in the food-limited deep sea is that it is low to extremely low. So the relationship between productivity is likely to be simple and linear, with increased productivity always raising diversity. There is unlikely to be a productivity high enough to decrease diversity. This is demonstrated by analysis of the relationship of sample diversity with depth from the deep sea into shallow water. Various data show a unimodal curve, e.g. nematodes (Boucher \& Lambshead 1995), poly- chaetes (Paterson \& Lambshead 1995), gastropods (Stuart 1991) and macrofauna (Rex 1981, 1983, Blake et al. 1985, 1987), with diversity only declining in the higher productivity regime found in shallow water.

At the same time, the modern deep sea does not display wide variations in temperature. Temperature tends to be uniformly cold and not latitude-dependent. Rohde's (1992) hypothesis should not apply to the modern deep sea and so this environment should be a suitable place to test for a productivity-linked diversity gradient over latitudinal distances.

Note that, historically, the deep sea has undergone temperature changes that may have an impact on historical patterns. For example, Thomas \& Gooday (1996) studied Foraminifera diversity in association with temperature in cores from 2 sites in the equatorial Pacific and Weddell Sea, Antarctica, from 58 million yr ago, the late Paleocene, to the present day. The temperature in the 2 locations diverged at about 38 million yr ago, the Weddell Sea being cooler. Associated with this change was a corresponding lower diversity in the Antarctic.

This is a fascinating result because the organic flux into the Weddell Sea increased. It is difficult to believe that this modest increase in productivity, by shallow water standards, was sufficiently high to depress diversity. Thomas \& Gooday (1996) speculate that the decrease in diversity was a disturbance effect due to 'the onset of a more unpredictable and seasonally fluctuating food supply'. However, as they point out, current deep-sea theory suggests that such unpredictability should increase diversity through increased heterogeneity (Grassle \& Morse-Porteus 1987, Grassle \& Maciolek 1992), as apparently demonstrated by Brown et al. (in press). On the other hand it seems possible that Thomas \& Gooday's results over geological time scales might fit Rohde's hypothesis of slower evolutionary rates being the controlling mechanism.

\section{INVESTIGATION OF LATITUDINAL GRADIENTS IN THE MODERN DEEP SEA}

There are no entirely adequate data to investigate latitudinal gradients in the deep sea. Quantitative deep-sea samples can be taken with corers but few cores have been worked up to species level. Approximately $2 \mathrm{~km}^{2}$ of the deep sea have been sampled for macrofauna (Paterson 1993) and less than $5 \mathrm{~m}^{2}$ for meiofauna (Lambshead 1993). Larger animals have been sampled more extensively with epibenthic sledges but these are qualitative or, charitably, semiquantitative samples. So the first problem is lack of data. 
A further problem with available deep-sea diversity data is that it was never collected with the specific intention of assessing large-scale diversity gradients. So data have to be assernbled from a variety of projects. Samples are collected in clusters at stations for reasons connected with the original research. This presents statistical problems, as the stations, not the samples, are randomly selected with respect to the analysis. The samples are pseudoreplicates, but omitting pseudoreplicates further decreases the available data.

A final problem comes with the way diversity is usually calculated by deep-sea biologists. Terrestrial latitudinal gradient analysis tends to use some measure of species count per place/region/area while deep-sea science commonly employs rarefaction.

Discussion has centred on the utility of the rarefaction method (Sanders 1968, Hurlbert 1971) for species diversity analysis (Gage \& May 1993). Rarefaction, when used as expected number of species, is a diversity index and, as such, is considered to incorporate equitability as well as species richness. Equitability is a measure of the evenness, or relative abundance, of species in an assemblage. Gray (1997) demonstrated empirically how the response of rarefaction to equitability differences can bias species richness estimates.

Rarefaction also assumes that individuals from a species or assemblage are randomly distributed in space. However, deep-sea nematodes tend to be aggregated, and worse still, for diversity-productivity analysis, the degree of aggregation increases with organic flux (Lambshead \& Hodda 1994, Rice \& Lambshead 1994). This appears to be true for other small organisms (Lambshead \& Gooday 1990) and is probably true for other larger benthic organisms which have too low an abundance to be statistically tested for aggregation. Lauerman \& Kaufmann (1998) have recently demonstrated that epibenthic echinoderms clump around detrital material but are otherwise randomly distributed.

Diversity indices are normally used for measuring the effects of local ecological processes, such as disturbance, on diversity rather than for assessing largescale biogeographic trends. Analysis has suggested that the greater the component of equitability within an index, the less useful the index is for large-scale comparisons (Boucher \& Lambshead 1995). To conclude, there are a number of theoretical reasons for thinking that rarefaction may be unsuitable for analysing biogeographic diversity patterns especially if these are expected to be associated with food resource gradients.

It is unfortunate that the most comprehensive data we have for deep-sea organisms are for the North Atlantic rather than the Pacific Ocean. The North Atlantic is divided into a series of basins, each of which may be expected to have its own individual ecology. Extracting a single large-scale biogeographic pattern from these individual, potentially conflicting ecological signals is problematical, especially if an ecological diversity index is used for the analysis. In particular, lateral transport of organic flux from the coastal regions into the deep sea is likely to introduce effectively random elements into any large-scale gradient linking diversity to primary productivity in the surface waters.

A cogent argument can be made for the position that extant deep-sea data are too inadequate for any latitudinal analysis because they are too sparse, unacceptably chustered, and collected from the wrong ocean. However, new data will only be acquired slowly and are likely to possess many of the inadequacies of the old data for much the same reasons. It seems therefore worthwhile to attempt to test for latitudinal gradients with the data we have while bearing in mind their problems.

Latitudinal gradients were reported in the deep Atlantic for 3 taxa of macrobenthos; Isopoda, Gastropoda and Bivalvia (Rex et al. 1993, 1997). The data used were collected by semi-quantitative epibenthic sledge and analysed as individual pseudoreplicates using rarefaction. The result was a decline towards the high latitudes in the North Atlantic with a variable pattern from 0 to $40^{\circ} \mathrm{S}$.

This result contradicts the predicted relationship between diversity and productivity in the deep sea. Productivity of the deep, North Atlantic, benthos depends on the flux of material from primary production in the surface layers and lateral transport both from the surface and from the shore. So it can be difficult to estimate but, broadly speaking, surface production increases polewards in the North Atlantic (Campbell \& Aarup 1992). So a productivity mechanism is unlikely to explain the patterns reported by Rex et al. (1993, 1997) for the resource-limited deep sea.

An alternative suggestion, that diversity is correlated with size of environmental region (Terborgh 1973, Abele \& Walters 1979a,b), might be applicable. The proportions of deep sea available at different latitudes in the North Atlantic could give a pattern of declining diversity at higher latitudes and, to some degree, in the equatorial region. Historical processes at high latitudes in the North Atlantic could exacerbate this geographic effect.

Gray (1994) noted that the pattern reported by Rex et al. $(1993,1997)$ 'was largely determined by the low diversity shown in the deep-sea area of the Norwegian Sea'. Rex et al. (1997) disputed this point but it is clear that of the 3 taxa, the bivalve gradient is entirely dependent on the Norwegian Sea, and the gradients in isopods and gastropods are far less convincing without 
this region. As Rex et al. (1997) admit, 'The Norwegian Sea is a relatively small, shallow and partially isolated basin that may impose higher extinction rates and offer less ecological opportunity than the larger and more confluent basins to the south in the Atlantic'. So size, geographic isolation and the Quaternary glaciation (Dahl 1972, Svavarsson et al. 1993) suggest that the Norwegian Sea may be distinct from the rest of the Atlantic system.

A paper by Brey et al. (1994) offers further evidence that the Norwegian Sea may be unusual for reasons specific to the region. These authors compared Weddell Sea diversities of the 3 deep-sea taxa with the results reported by Rex et al. (1993). They show that 'there is no steady latitudinal decrease in deep-sea benthic diversity towards south polar regions'. Again, Rex et al. (1997) disputed the point on the grounds that Brey et al.'s data are from Agassiz trawls while their data originate from epibenthic sledges (thus altering the class size investigated). Comparison of results from trawls and sledges is not ideal but Brey et al.'s results cannot be entirely dismissed. Finally, a recent analysis of asteroid diversity by Price et al. (1999) failed to find deep-sea latitudinal gradients.

\section{HYPOTHESES TO BE TESTED}

It is possible to synthesise 3 hypotheses that can be tested by deep-sea marine nematode data from the North Atlantic: (1) The use of rarefaction for detecting biogeographic species richness can be problematical because of its sensitivity to equitability. (2) The Norwegian Sea has an unusually low diversity relative to the rest of the North Atlantic. (3) Deep-sea nematode diversity is positively associated with primary production.

\section{NEMATODE ANALYSES}

This paper utilises marine nematode data. Nematodes are by far the most abundant metazoan taxon in the deep sea and appear to have a high diversity (May 1988, Gaston 1991, Lambshead 1993). Deep-sea nematode diversity has been investigated for only a limited number of data sets (see Lambshead et al. 1994; Boucher \& Lambshead 1995), mostly from the North Atlantic. The data employed here are listed in Table 1. Care was taken only to employ samples that were reasonably compatible in both sampling and taxonomic terms. For example, only data generated from box cores or multiple cores were used. The arguments for what constitutes 'reasonableness' in this context for these data are set out in Boucher \& Lambshead (1995). Sixty-nine samples of marine nematodes were available for analysis from 17 locations.

In this paper, rarefaction statistics (ES[51]) are compared with a species count per station. Because ships collect clusters of samples at sites, it is the sites that are independent, not the samples, so means obtained from rarefaction analysis of the samples from a site are used

Table 1 . The sites, their latitude to the nearest degree north, the mean and standard deviation of the ES(51) rarefaction statistics for the cores from the site, the species count from the site, and the number of cores and nematodes on which the analysis is based. - Site with major sediment disturbance

\begin{tabular}{|c|c|c|c|c|c|c|}
\hline Station & $\begin{array}{l}\text { Latitude } \\
\left({ }^{\circ} \mathrm{N}\right)\end{array}$ & $\begin{array}{l}\text { Depth } \\
\text { (m) }\end{array}$ & $\begin{array}{c}\text { Mean } \\
\text { ES(51) }\end{array}$ & $\mathrm{SD}$ & $\begin{array}{l}\text { Species } \\
\text { count }\end{array}$ & $\begin{array}{l}\text { No. of individ- } \\
\text { uals (cores/ } \\
\text { nematodes) }\end{array}$ \\
\hline Norwegian Sea & 68 & 1332 & 24.07 & 1.63 & 73 & $6 / 1629$ \\
\hline Rockall Trough, $545 \mathrm{~m}$ & 56 & 545 & 28.72 & 0.13 & 81 & $3 / 304$ \\
\hline Rockall Trough, $835 \mathrm{~m}$ & 56 & 835 & 31.08 & 2.36 & 83 & $3 / 292$ \\
\hline Rockall Trough, $1474 \mathrm{~m}$ & 57 & 1474 & 27.39 & 1.23 & 93 & $3 / 334$ \\
\hline Porcupine Abyssal Plain (1989) & 49 & 4850 & 28.80 & 2.14 & 131 & $6 / 1256$ \\
\hline Porcupine Abyssal Plain (1991) & 49 & 4850 & 32.92 & 1.11 & 156 & $6 / 1428$ \\
\hline HEBBLE Stn 1" & 40 & 4626 & 24.94 & 2.98 & 133 & $8 / 1331$ \\
\hline HEBBLE Stn $2^{\circ}$ & 40 & 4626 & 25.26 & 1.40 & 124 & $9 / 1152$ \\
\hline Madeira Abyssal Plain" & 31 & 4950 & 25.39 & 1.21 & 78 & $6 / 578$ \\
\hline Hatteras Abyssal Plain & 32 & 5411 & 29.95 & 1.05 & 88 & $2 / 507$ \\
\hline Puerto Rico Trench $1^{*}$ & 19 & 7460 & 25.36 & 1.00 & 55 & $3 / 344$ \\
\hline Puerto Rico Trench $2^{\circ}$ & 20 & 8189 & 22.4 .3 & 0.48 & 47 & $3 / 284$ \\
\hline Puerto Rico Trench $3^{\circ}$ & 20 & 8380 & 21.59 & 4.04 & 46 & $3 / 394$ \\
\hline Puerto Rico Trench 5 & 19 & 2217 & 26.78 & 1.06 & 63 & $2 / 339$ \\
\hline Venezuela Basin 1 & 15 & 3858 & 27.21 & 2.04 & 54 & $2 / 309$ \\
\hline Venezuela Basin 2* & 13 & 5054 & 31.78 & 2.19 & 73 & $2 / 270$ \\
\hline Venezuela Basin 3 & 13 & 3517 & 32.13 & 0.98 & 85 & $2 / 425$ \\
\hline
\end{tabular}


Table 2. Pearsons correlations for the rarefaction index, ES(51), species count, depth, and latitude (including Norwegian Sea data/excluding Norwegian Sea data). "Significant at the 0.05 level, " significant at the 0.025 level

\begin{tabular}{|lccc|}
\hline & Latitude & ES(51) & $\begin{array}{c}\text { Species } \\
\text { count }\end{array}$ \\
\hline $\begin{array}{l}\text { ES(51) } \\
\text { Species } \\
\text { Count }\end{array}$ & $0.0794 \cdot / 0.616^{*}$ & $0.426 / 0.415$ & \\
Depth & $-0.610^{*} \cdot /-0.553^{\circ}$ & $-0.401 /-0.522$ & $-0.180 /-0.225$ \\
\hline
\end{tabular}

as datum points in this analysis and the counts are calculated per site, not per sample.

Table 2 shows Pearson correlations for the 2 diversity measures, latitude, and depth. Note that depth inversely correlates with latitude in the North Atlantic. ES(51) correlated poorly with any of the parameters except a modest but insignificant correlation with species count. Species count showed a positive correlation with latitude but fortunately no correlation with depth.

Fig. 1 shows rarefaction means (ES[51]) for sites plotted against latitude. There was no correlation between latitude and the rarefaction statistic (excluding the Norwegian Sea, the plotted regression of ES[51] on latitude was $\mathrm{R}^{2}=5.3 \%, \mathrm{p}=0.393$; including the Norwegian Sea, the regression of ES[51] on latitude was $\mathrm{R}^{2}=$ $0.6 \%, p=0.766$ ). The sites were divided arbitrarily into 2 blocks by the $35^{\circ} \mathrm{N}$ line and tested using Student's $t$ (excluding the Norwegian Sea) (Table 3 ). The $35^{\circ}$ line was chosen because it roughly divides the ocean basins in half. There was no significant difference between the 2 blocks. Including the Norwegian Sea

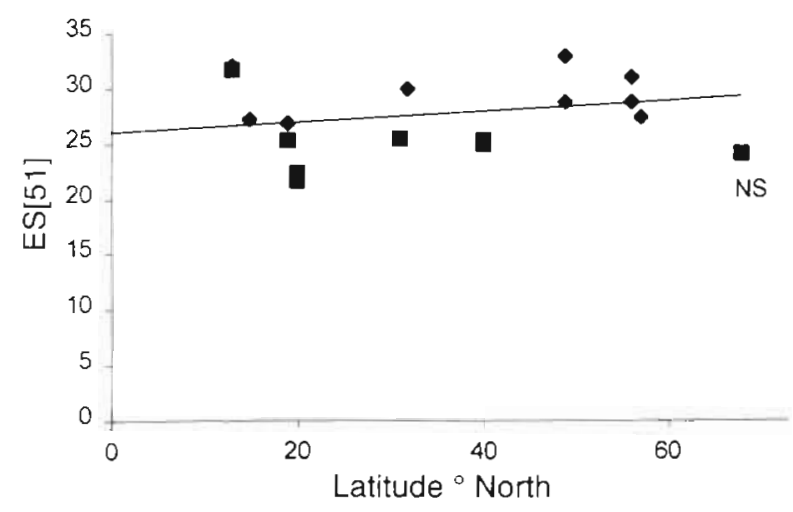

Fig. 1 Rarefaction (ES[51]) means derived from replicate samples of marine nematodes from a number of sites in the North Atlantic plotted against latitude. (a) Stations subject to physical disturbance; NS: Norwegian Sea site. Excluding the Norwegian Sea the regression equation is: $\operatorname{ES}(51)=26.1+$ 0.0471 latitude. $R^{2}=5.3 \%, p=0.393$
Table 3. Comparison of the mean ES(51) scores for sites north of $35^{\circ} \mathrm{N}$ versus sites south of this latitude using a 2 sample t-test (excluding the Norwegian Sea)

\begin{tabular}{|lccc|}
\hline Sites & $\begin{array}{c}\text { Mean } \\
\text { ES(51) }\end{array}$ & SD & No. of sites \\
\hline Northern & 28.44 & 2.91 & 7 \\
Southern & 26.96 & 3.76 & 9 \\
& & & $\begin{array}{c}\mathrm{p}=0.393 \\
\text { not significant }\end{array}$ \\
\hline
\end{tabular}

merely reduces the difference between the means, increasing the lack of significance. We conclude that rarefaction analysis shows no evidence for a latitudinal gradient.

It remained to test whether this result was because there was no latitudinal gradient of diversity in deepsea nematode data in the North Atlantic or because rarefaction was influenced too strongly by local ecology in the complex Atlantic basins. To test for the influence of ecology on rarefaction, we divided the samples into those from areas influenced by physical processes sufficient to move sediment, and reference sites. The low diversity Norwegian Sea was excluded to avoid influencing the ecological analysis by its known specific history. The deep sea suffers less from physical disturbance than coastal habitats but high-energy water currents have been shown to affect the diversity of infaunal organisms, e.g. at the HEBBLE high energy stations (Thistle \& Sherman 1985).

Sediment analysis suggested that the Madeira Abyssal Plain Stn P (Lambshead \& Hodda 1994) and Venezuela basin Stn 2 (Tietjen 1984) had been affected by turbidites, and HEBBLE by severe benthic storms (Thistle \& Sherman 1985). The deep-trench sites such as Puerto Rico 1, 2 and 3 (Tietjen 1989) were included in this group because of sediment slides from the canyon slopes (Grassle 1989). The undisturbed ES(51) cores had a significantly higher diversity than the disturbed cores (Table 4), demonstrating how diversity indices for deep-sea infauna can be influenced by local ecology. It is noteworthy that the mean ES(51) for the Norwegian Sea $(24.07)$

Table 4. Comparison of the mean ES(51) scores for sites with undisturbed sites versus sites with disturbed sediments using a 2 sample $t$-test (excluding the Norwegian Sea)

\begin{tabular}{|lccc|}
\hline Sites & Mean & SD & No. of sites \\
\hline Undisturbed & 29.06 & 2.12 & 8 \\
Disturbed & 25.32 & 2.27 & 7 \\
& & & $p=0.026$ \\
& & & significant \\
\hline
\end{tabular}


was low compared to the mean for physically impacted sites (25.32).

We must stress that this test is not an investigation. into physical disturbance effects on deep-sea nematodes (it is too crude for that), but it is an illustration of how effective and sensitive rarefaction can be for detecting local ecology, even where the test is crude. The efficacy of rarefaction in this context has been pointed out by other authors (e.g. Brewer \& Williamson 1994). It is interesting how little deep-sea nematode diversity was depressed by physical disturbance at sites such as HEBBLE. Physical disturbance is known to have a bigger impact on macrofauna than on meiofauna diversity in shallow studies (e.g. Austen et al. 1989, Warwick et al. 1990).

The next step was to test whether species richness as measured by species count gave a better biogeographic signal than rarefaction. The ideal method for benthic data is to plot species count against area. Unfortunately, the subsampling system used for diversity analysis of deep-sea nematode cores makes this problematical. Gray (1994) has plotted species against cumulative area and species against cumulative number of individuals for benthic fauna and found close agreement between the plots. So in this analysis, a plot of species count against number of individuals is used as an alternative to a plot of species count against area.

The plot of species count against number of individuals (Fig. 2) showed a strong positive correlation (excluding the Norwegian Sea, the plotted regression of species count on number of individuals was $R^{2}=$ $81.8 \%, p<0.001$; including the Norwegian Sea gives a regression line of $\left.\mathrm{R}^{2}=51.1 \%, \mathrm{p}=0.001\right)$. This close correlation was the expected result assuming no

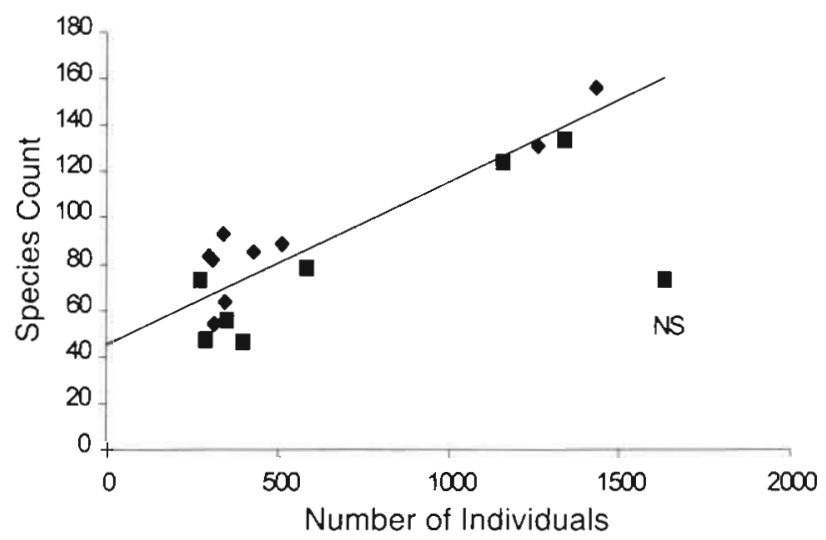

Fig. 2. Count of marine nematode species per North Atlantic site plotted against the number of individuals in the samples at that site. (ם) Stations subject to physical disturbance; NS: Norwegian Sea site. Excluding the Norwegian Sea the regression equation is: species count $=44.8+0.0705$ number of individuals. $\mathrm{R}^{2}=81.8 \%, \mathrm{p}<0.001$

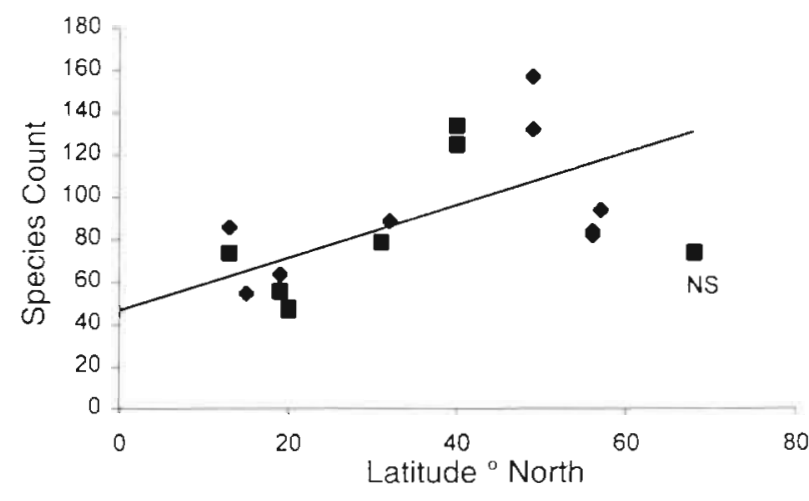

Fig. 3. Species count plotted against latitude for a number of sites in the North Atlantic. (ם) Stations subject to physiral disturbance; NS: Norwegian Sea site. Excluding the Norwegian Sea the regression equation is: species count $=46.0+1.24$ latitude. $\mathrm{R}^{2}=37.9 \%, \mathrm{p}=0.011$

large-scale environmental or historical influences. However, the Norwegian Sea was clearly an outlier. It demonstrated reduced species richness even more notably for species count than rarefaction data. This result supports the view expressed by Rex et al. (1997) that this region is different in some way from the other basins of the North Atlantic. An impact of ecological disturbance was not evident in the species counts. These results demonstrate Gage \& May's (1993) and Gray's (1997) points.

The plot of species count against latitude (Fig. 3) showed a weaker but significant correlation (excluding the Norwegian Sea, the plotted regression of species count on latitude was $\mathrm{R}^{2}=37.9 \%, \mathrm{p}=0.011$; including the Norwegian Sea gives $R^{2}=24.3 \%, p=0.044$ ). This is not convincing as the line is heavily influenced by the large samples at 40 to $50^{\circ} \mathrm{N}$. To remove the impact of the strong correlation between species count and number of individuals, the regression equation for species count on number of individuals and latitude was calculated and is shown in Table 5. If number of individuals was removed from the regression a significant positive regression $(p=0.008)$ was still obtained for latitude. In short, there appears to be evidence for a positive latitudinal gradient from 13 to $56^{\circ} \mathrm{N}$

Table 5. Regression of species count (SC) on number of individuals (NI) and latitude (LT). $\mathrm{SC}=30.2+0.0611 \mathrm{NI}+0.611$ $(S D=0.195) L T . R^{2}=89.6 \%$

\begin{tabular}{|lrrrrr|}
\hline Source & df & SS & MS & $F$ & $p$ \\
\hline NI (ignoring LT) & 1 & 13520 & 13520 & & \\
LT (adjusted for NI) & 1 & 1291 & 1291 & 9.81 & 0.008 \\
Error & 13 & 1711 & 131.6 & & \\
Total & 15 & 16522 & & & \\
& & & & & \\
\hline
\end{tabular}




\section{CONCLUSIONS}

Any conclusions about deep-sea latitudinal gradients remain equivocal because (1) the data are both quantitatively and qualitatively inadequate and (2) the Atlantic is not an ideal place to collect data for such a study because of its division into basins, the problematical inclusion of the Norwegian Sea, and lateral transport of organic flux from the coast. But a few tentative conclusions may be reached.

It must be concluded that Gage \& May (1993) and Gray (1997) were correct to warn about rarefaction as a potentially misleading measure of large-scale biogeographic patterns possibly because of its sensitivity to equitability and, hence, local ecology. So Hypothesis 1 is accepted.

The nematode data suggest that the Norwegian deep sea is noticeably different from other Atlantic basins, which is why Brey et al. (1994) did not find diversity similarly depressed in the South Atlantic. So Hypothesis 2 is accepted.

A complex productivity pattern with a positive south-north component appears responsible for a positive latitudinal gradient in deep-sea nematode diversity in the Atlantic between 13 and $56^{\circ} \mathrm{N}$. The gradient is consistent with the productivity argument for marine latitudinal diversity suggested by Roy et al. (1998). Although it must be emphasised that this result does not falsify the concept of an evolutionary process being responsible for latitudinal gradients, it appears to demonstrate that a historical mechanism is not necessarily needed to explain such a pattern if a productivity gradient is also present. So Hypothesis 3 is accepted, albeit tentatively.

This nematode pattern is quite different from those reported for gastropods, bivalves and isopods by Rex et al. (1993). Recent work has demonstrated that deepsea nematodes are closely coupled to the organic flux (Lambshead \& Hodda 1994, Cook et al. 1999, Brown et al. in press). It may be that the diversity of relatively larger, and rarer, organisms are less linked to organic flux, and are more influenced by historical-geographi$\mathrm{cal}$ events in the high latitudes of the North Atlantic (Rex et al. 1997, p. 115).

Conclusions about the mechanisms of deep-sea latitudinal gradients must be considered speculative until further research has validated the observed patterns. Two areas would be especially fruitful for research. The first is to investigate the latitudinal diversity patterns of polychaetes in the Atlantic. Polychaetes also show a close association with organic flux compared to molluscs (see Cook et al. 1999) and if these conclusions are correct we predict that polychaete diversity should show similar patterns to nematode diversity.
Secondly, it would be extremely helpful to test these conclusions in a less complex area than the North Atlantic. Smith et al. (1997) have shown a strong association between the benthos and latitudinal changes in organic flux in the abyssal equatorial Pacific. This region is geographically simpler than the North Atlantic, being less divided into basins and separated from coastal influences. It also lacks the historical events that have influenced the Norwegian Sea. If the conclusions in this paper are correct, we may predict a deep-sea nematode, and possibly polychaete, organic flux-influenced, latitudinal diversity gradient in the equatorial Pacific that declines from the equator to the north. This pattern should be absent or much less pronounced in mollusc or isopod diversity data. An additional prediction is that diversity patterns indicated by diversity indices should be similar to species richness as indicated by a species count, because of the less complex ecological situation in the equatorial Pacific.

Acknowledgements. The authors would like to thank David Thistle for kindly allowing us to use his HEBBLE data, and Caroline Brown, Sir Robert May, Craig Smith, and Paul Snelgrove for critically reading the manuscript. John Gage, Andrew Gooday, Frederick Grassle, Clive Moncrieff, Gordon Paterson and Andrew Price generously advised the authors.

\section{LITERATURE CITED}

Abele LG, Walters K (1979a) The stability-time hypothesis: reevaluation of the data. Am Nat 114:559-568

Abele LG, Walters K (1979b) Marine benthic diversity: a critique and alternative explanation. J Biogeogr 6:115-126

Angel MV (1993) Biodiversity of the pelagic ocean. Conserv Biol 7:760-772

Austen MC, Warwick RM, Rosado MC (1989) Meiobenthic and macrobenthic community structure along a putative pollution gradient in southern Portugal. Mar Pollut Bull 20:398-405

Blake JA, Hecker B, Grassle JF, Maciolek-Blake N, Brown B, Curran M. Dade B, Freitas S, Ruff RE (1985) Study of biological processes on the US South Atlantic slope and rise. Phase 1. Benthic characterisation study. Final report prepared for the US Department of Interior, Minerals Management Service, Washington, $D C$

Blake JA, Hecker B, Grassle JF, Brown B, Wade M, Boehm P, Baptiste E, Hillbig B, Maciolek N, Petrecca R, Ruff RE, Starczak V, Watling LE (1987) Study of biological processes on the US South Atlantic slope and rise. Phase 2. Benthic characterisation study. Final report prepared for the US Department of Interior, Minerals Management Service, Washington, DC

Boucher G, Lambshead PJD (1995) Ecological biodiversity of marine nematodes in samples from temperate, tropical, and deep-sea regions. Conserv Biol 9:1594-1604

Brewer A, Williamson M (1994) A new relationship for rarefaction. Biod Cons 3:373-379

Brey T, Klages M, Dahm C, Gorny M, Gutt J, Hahn S, Stiller $M$, Arntz WE, Wagele JW, Zimmerman A (1994) Antarctic benthic diversity. Nature 368:297 
Brown CJ, Lambshead PJD, Ferrero TJ, Smith CR, Hawkins, LE (in press) Phytodetritus causes an increase in abyssal nematode biodiversity at local scales: a lest in the equatorial Pacific. In: Lambshead PJD, Bamber $R$, Sherwood B (eds) Contemporary issues in marine biodiversity. Westburg Publishing, Otley

Campbell JW, Aarup T (1992) New production in the North Atlantic derived from seasonal patterns of surface chlorophyll. Deep-Sea Res 39:1669-1694

Coates $M$ (1998) A comparison of intertidal assemblages on exposed and sheltered tropical and temperate rocky shores. Global Ecol Biogeogr Lett 7:115-124

Cook AA, Lambshead PJD. Hawkins LE, Mitchell N, Levin LA (1999) Nematode abundance at the oxygen minimum zone in the Arabian Sea. Deep-Sea Res 47:75-85

Dahl E (1972) The Norwegian Sea deep water fauna and its derivation. Ambio Spec Rep 2:19-24

Dauvin JC, Kendall M, Paterson G, Gentil F, Jirkov I, Sheader $M$ (1994) An initial assessment of polychaete diversity in the northeastern Atlantic Ocean. Biodivers Lett 2:171-181

Gage JD, May RM (1993) A dip into the deep seas. Nature 365:609-610

Gaines SD, Lubchenco J (1982) A unified approach to marine plant-herbicide interactions. II. Biogeography. Annu Rev Ecol Syst 13:111-138

Gaston KJ (1991) The magnitude of global insect species richness. Conserv Biol 5:283-296

Grassle JF (1989) Species diversity in deep-sea communities. Trends Ecol Evol 4:12-15

Grassle JF, Maciolek NJ (1992) Deep sea species richness: regional and local diversity estimates from quantitative bottom samples. Am Nat 139:313-341

Grassle JF, Morse-Porteus LS (1987) Macrofaunal colonisation of disturbed deep-sea environments and the structure of deep-sea benthic communities. Deep-Sea Res 34:1911-1950

Gray JS (1994) Is deep-sea biodiversity really so high? Species diversity of the Norwegian continental shelf. Mar Ecol Prog Ser 112:205-209

Gray JS (1997) Gradients in marine biodiversity. In: Ormond RFG, Gage JD, Angel MV (eds) Marine biodiversity. Cambridge University Press, Cambridge, p 18-34

Grime (1973) Control of species density in herbaceous vegetation. J Environ Manage 1:151-167

Hicks RF, Coull BC (1983) The ecology of marine meiobenthic harpacticoid copepods. Oceanogr Mar Biol 21:67-175

Hodda M, Bloemers GF, Wanless FR, Lambshead PJD (1995) Nematodes and carbon flux in a tropical rainforest in Cameroon: preliminary results. In: Nilsson LO, Huttl RF, Johansson UT, Mathy P (eds) Nutrient uptake and cycling in forest ecosystems. EC Ecosystem research report No. 21, Office for Official Publications of the EC, Luxembourg, p $131-137$

Humboldt A, Bonpland A (1807) Essai sur la geographie des plantes accompagne d'une tableau physique des regions equinoxiales. Arno Press, New York (reprinted 1977)

Hurlbert SH (1971) The non-concept of species diversity: a critique and alternative parameters. Ecology 52:577-586

Huston $M$ (1979) A general hypothesis of species diversity. Am Nat 113:81-101

Kendall MA, Aschan M (1993) Latitudinal gradients in the structure of macrobenthic communities: a comparison of Arctic, temperate and tropical sites. J Exp Mar Biol Ecol 172:157-169

Lambshead PJD (1993) Recent developments in marine benthic biodiversity research. Oceanis 19:5-24

Lambshead PJD, Gooday AJ (1990) The impact of seasonallydeposited phytodetritus on epifaunal and shallow infaunal benthic foraminiferal populations in the bathyal northeast Atlantic: the assemblage response. Deep-Sea Res 37 $1263-1283$

Lambshead PJD, Hodda M (1994) The impact of disturbance on measurements of variability in marine nematode populations. Vie Milieu 44:21-27

Lambshead PJD, Elce BJ, Thistle D, Eckman JE, Barnett PRO (1994) A comparisonof the biodiversity of deep-sea marine nematodes from three stations in the Rockall Trough, Northeast Pacific. Biodivers Lett 2:95-107

Lasserre P (1992) The role of biodiversity in marine ecosystems. In: Solbrig OT, van Emden HM, van Oordt PGWJ (eds) Biodiversity and global change. International Union of Biolgical Sciences, Paris, p 105-130

Lauerman LML, Kaufmann RS (1998) Deep-sea epibenthic echinoderms and a temporally varying food supply: results from a one year time series in the NE Pacific. Deep-Sea Res 45:817-842

May R (1988) How many species are there on earth? Science 241:1441-1449

McGowan JA, Walker PW (1993) Pelagic diversity patterns. In: Ricklefs R, Schluter D (eds) Species diversity in ecological communities: historical and geographical perspectives. University of Chicago Press, Chicago, p 203-214

Paterson GLJ (1993) Patterns of polychaete assemblage structure from bathymetric transects in the Rockall Trough, NE Atlantic Ocean. PhD thesis, University of Wales, Cardiff, Swansea

Paterson GLJ, Lambshead PJD (1995) Bathymetric patterns of polychaete diversity in the Rockall Trough, north-east Atlantic. Deep-Sea Res 42:1199-1214

Price ARG, Keeling MJ, O'Callaghan CJ (1999) Ocean-scale patterns of 'biodiversity' of Atlantic asteroids determined from taxonomic distinctness and other measures. Br J Linn Soc 66:187-203

Proctor DLC (1990) Global overview of the functional roles of soil living nematodes in terrestrial communities and ecosystems. J Nematol 22:1-7

Reid JL, Brinton E, Fleminger A, Venrick EL, McGowan JA (1978) Ocean circulation and marine life. In: Charnock $H_{\text {, }}$ Deacon Sir G (eds) Advances in oceanography. Plenum Press, New York, p 65-130

Rex MA (1981) Community structure in the deep-sea benthos. Annu Rev Ecol Syst 12:331-353

Rex MA (1983) Geographic patterns of species diversiuty in the deep-sea benthos. In: Rowe GT (ed) The sea, Vol 8. John Wiley, New York, p 453-474

Rex MA, Stuart CT, Hessler RR, Allen JA, Sanders HL, Wilson GDF (1993) Global scale latitudinal patterns of species diversity in the deep-sea benthos. Nature 365:636-639

Rex MA, Etter RJ, Stuart CT (1997) Large-scale patterns of species diversity in the deep-sea benthos. In: Ormond RFG, Gage JD, Angel MV (eds) Marine biodiversity. Cambridge University Press, Cambridge, p 94-121

Rice AL, Lambshead PJD (1994) Patch dynamics in the deepsea benthos: the role of a heterogeneous supply of organic matter. In: Giller PS, Hildrew AG, Raffaelli DG (eds) Aquatic ecology: scale, pattern and process. 34th Symposium of The British Ecological Society. Blackwell Scientific Publications, Oxford, p 469-499

Rohde K (1992) Latitudinal gradients in species diversity: the search for a primary cause. Oikos 65:514-527

Rosenzweig ML (1995) Species diversity in space and time. Cambridge University Press, Cambridge

Roy K, Jablonski D, Valentine JW, Rosenberg G (1998) Marine latitudinal diversity gradients; tests of causal hypotheses. Proc Natl Acad Sci USA 95:3699-3702 
Sanders HL (1968) Marine benthic diversity: a comparative study. Am Nat 102:243-282

Santelices B (1989) Algas marinas de Chile. Ediciones Universidad Catolica de Chile, Santiago

Smith CR, Berelson W, Demaster DJ, Dobbs FC, Hammond D, Hoover DJ, Pope RH, Stephens M (1997) Latitudinal variations in benthic processes in the abyssal equatorial Pacific: control by biogenic particle flux. Deep-Sea Res 44 : 2295-2317

Stehli FG, McAlester AL, Helsley CE (1967) Taxonomic diversity of recent bivalves and some implication for geology. Geol Soc Am Bull 78:455-466

Stehli FG, Douglas RG, Newell ND (1969) Generation and maintenance of gradients in taxonomic diversity. Science $164: 947-949$

Stuart CT (1991) Regional and global diversity patterns of deep-sea gastropods in the Atlantic Ocean. PhD thesis, University of Massachusetts, Boston

Svavarsson J, Stromberg JO, Brattegard T (1993) The deep sea asellote (Isopoda: Crustacea) fauna of the Northern Seas: species composition, distributional pattern and origins. J Biogeogr 20:537-555

Terborgh J (1973) On the notion of favorableness in plant ecology. Am Nat 112:583-593

Thistle D, Sherman KM (1985) The nematode fauna of a deep-

Editorial responsibility: John Gray (Contributing Editor),

Oslo, Norway sea site exposed to strong near-bottom currents. Deep-Sea Res 32:1077-1088

Thomas E, Gooday AJ (1996) Cenozoic deep-sea benthic foraminifers: tracers for changes in oceanic productivity. Geology 24:355-358

Thorson G (1952) Zur jetzigen Lage der marinen BodentierÖkologie. Zool Anz 16:276-327

Thorson G (1957) Bottom communities (sublitoral or shallow shelf). In: Hedgepeth JW (ed) Treatise on marine ecology and paleoecology. Geological Society of America, New York, p 461-534

Tietjen JH (1984) Distribution and species diversity of deepsea nematodes in the Venzuella Basin. Deep-Sea Res 31 : $119-132$

Tietjen JH (1989) Ecology of deep-sea nematodes from the Puerto Rico Trench area and Hatteras Abyssal Plain. Deep-Sea Res 36:1579-1594

Warwick RM, Ruswahyuni (1987) Comparative study of the structure of some tropical and temperate marine soft bottom macrobenthic communities. Mar Biol 95:641-649

Warwick RM, Platt HM, Clarke KR, Agard J, Gobin J (1990) Analysis of macrobenthic and meiobenthic community structure in relation to pollution and disturbance in Hamilton Harbour, Bermuda. J Exp Mar Biol Ecol 138: $119-142$

Submitted: March 31, 1999; Accepted: September 28, 1999 Proofs received from author(s): February 21, 2000 